\title{
Results of the Technical Validation of an Accessible Contact Manager for Mobile Devices
}

\author{
Jon Azpiroz ${ }^{1}$, Juan Bautista Montalvá Colomer², \\ María Fernanda Cabrera-Umpiérrez ${ }^{2}$, María Teresa Arredondo ${ }^{2}$, and Julio Gutiérrez ${ }^{3}$ \\ ${ }^{1}$ Fundación Vodafone España, \\ Parque Empresarial La Moraleja \\ Avda. de Europa, 1; 28108 Madrid, Spain \\ ${ }^{2}$ Life Supporting Technologies, Universidad Politécnica de Madrid, \\ Ciudad Universitaria s/n, 28040 Madrid, Spain \\ ${ }^{3}$ Sección Departamental de Tecnología Fotónica, Universidad Politécnica de Madrid, \\ Campus de Montegancedo, 28660 Boadilla del Monte Madrid, Spain \\ jon.azpirozevodafone.com, \\ \{jmontalva, chiqui, mta\}@lst.tfo.upm.es, jgr@fi.upm.es
}

\begin{abstract}
The apparition of new mobile phones operating systems often leads to a flood of mobile applications rushing into the market without taking into account needs of the most vulnerable users groups: the people with disabilities. The need of accessible applications for mobile is very important especially when it comes to access basic mobile functions such as making calls through a contact manager. This paper presents the technical validation process and results of an Accessible Contact Manager for mobile phones as a part of the evaluation of accessible applications for mobile phones for people with disabilities.
\end{abstract}

Keywords: Accessible Contact Manager, Technical Validation, Evaluation, Mobile Phone Contact Manager.

\section{Introduction}

Nowadays, the emergence of new mobile operating systems like Android, iOS or W7, and the opening of new markets for mobile application (e.g. Android and Iphone markets) have led to the development of many applications sometimes not as accessible as they should be to be used by people with disabilities.

The accessibility of the applications is especially important when trying to perform basic activities with the mobile phone, such as selecting a contact or initiating a voice call. These actions may be difficult or even impossible to be made by persons with disabilities if the contact manager application is not accessible, and/or it is not properly configured and customized.

The European research project AEGIS [1] seeks to determine whether third generation access techniques will provide a more accessible, more exploitable and deeply 
embeddable approach in mainstream ICT (desktop, rich Internet and mobile applications). One of the specific deliverables of the AEGIS project is the development of an affordable Accessible Contact Manager application able to fill the accessibility gap of existing contact management applications for mobile phones. Designed for easy use by people with disabilities, in particular users with cognitive disabilities that currently have less presence when designing and developing accessible applications, the accessible contact manager user interface is configurable by: font size, colours with high contrast, position of contacts pictures and size configurable layout, explanatory text, customizable sounds alternative to images, and configurable button size. As shown in figure 1 , it is also operable with a touch screen, or with the joystick of the mobile phone keypad.

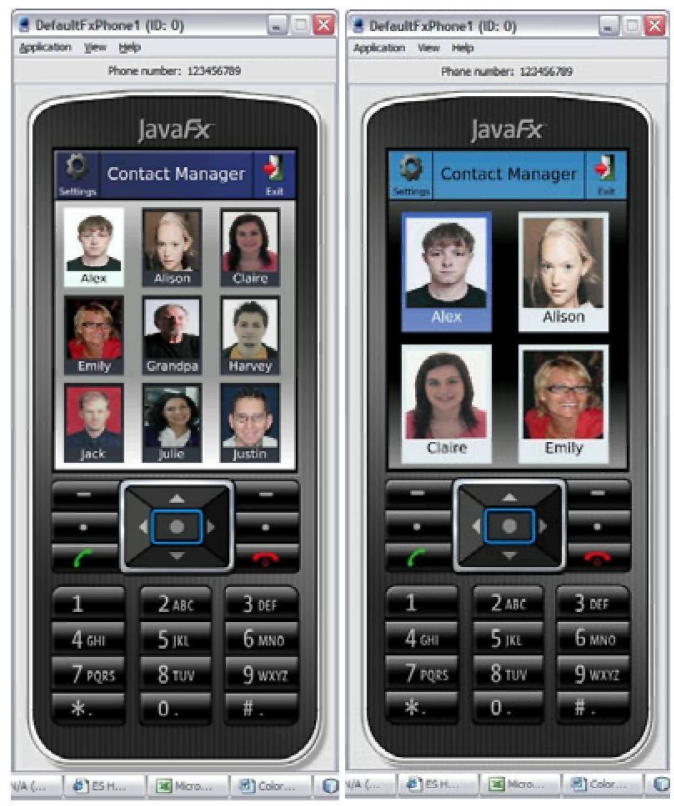

Fig. 1. Accessible Contact Manager Home page: left image with default configuration and right image with layout and colour theme modification

The development of the accessible contact manager has followed the process of "Design thinking" taking into account the current state of the contact management applications and the needs of disabled users in an iterative process of evaluation and technical validation.

\section{Evaluation Plan}

To provide a complete validation of the application, an evaluation plan was developed covering three iterative phases, according to the maturity of the application [2]. This 
plan contains a technical validation and human factors evaluation plan [3] [4] that follows a common approach. The scope of this paper covers the technical validation of the first phase iteration phase, when the application was still a prototype under development.

The technical validation plan for the first phase was based upon a technical validation research hypothesis according to the maturity of the Accessible Contact Manager and the development of different objectives and technical key indicators. Different scenarios covering several tasks/actions were developed to validate the technical key indicators with different automatic and manual measurement techniques, such as $\log$ files or manual verification metrics, to check the fulfilment of the success threshold.

\subsection{Technical Validation Research Hypothesis}

The Accessible Contact Manager will be considered successful, given that it provides a navigation of a list of contacts and their contact details in an appropriate time, without creating further problems. It should perform as a regular contact manager that is installed in any mobile device with adequate response times. In addition, the application should be able to adapt its layout and contents according to the user preferences taking into account the limitations of the mobile device.

\subsection{Main Technical Evaluation Objectives and Key Indicators}

The following table shows the technical key indicators, with metrics and success thresholds in order to check research hypothesis made.

\subsection{Technical Validation Procedure}

The technical validation was carried out in the usability and accessibility lab of Vodafone Spain Foundation. The log files were gathered automatically using a computer connected to the mobile device. The technical test was performed with two different mobile devices: HTC Diamond and Sony Ericsson Xpheria X2. Both devices run a Windows Mobile OS and had a JavaFX runtime installed to be able to run the application. The colour contrast was analysed manually using the Contrast Analyser Version 2.2 and the emulator version of the application that runs on the computer. To evaluate the intelligibility of the sounds, the mobile devices were configured with the system sound at maximum levels.

The technical validation consisted on a series of tasks that evaluated the technical characteristics of the application. Each task was focused on each of the technical key indicators that have been defined in table 1 . These are some examples of the tasks carried out:

Task 2 (focused on the second Key indicator of Table 1):

- Open NetBeans 6.8 IDE

- Connect the mobile device to the desktop computer using a USB cable 
- Synchronize the mobile device with the computer

- Run the contact manager project on the connected mobile device using NetBeans

- Use touch screen gestures to move up or down of the contact list

- Note down the time logs of the response time in a navigation movement using gestures with touch-screen

- Calculate the average response time

Task 7(focused on the seventh key indicator of Table 1): Go to the settings page and check the correct behavior of the application under these configurations:

- Small image size

- Medium image size

- Large image size

- Small font size

- Medium font size

- Large font size

- Dark background colour

- Light background colour

- Select English language

- Select Spanish language

- Select Dutch language

- Select Swedish language

Table 1. Main technical evaluation objectivs, key indicators, measuring tools and success thresholds for the Accessible Contact Manager

\begin{tabular}{|c|c|c|}
\hline Technical Key Indicators & $\begin{array}{l}\text { Metrics (for each indica- } \\
\text { tor) and ways/tools to } \\
\text { measure them }\end{array}$ & $\begin{array}{l}\text { Success Threshold (for each } \\
\text { metric) }\end{array}$ \\
\hline $\begin{array}{l}\text { Timeliness - Response time in a } \\
\text { navigation movement using the } \\
\text { joystick }\end{array}$ & Log files & 2 seconds $(0,2 \text { seconds })^{1}$ \\
\hline $\begin{array}{l}\text { Timeliness - Response time in a } \\
\text { navigation movement using } \\
\text { gestures with touch-screen }\end{array}$ & Log files & 2 seconds ( 0,2 seconds) \\
\hline $\begin{array}{l}\text { Timeliness - Response time in a } \\
\text { modification of the layout }\end{array}$ & Log files & $\begin{array}{l}15 \text { seconds (not available in } \\
\text { common contact managers) }\end{array}$ \\
\hline Reliability - Number of errors & $\begin{array}{l}\text { Log files and manual } \\
\text { evaluation }\end{array}$ & $\begin{array}{l}\text { Less than one error message } \\
\text { per } 50 \text { user interactions with } \\
\text { the device }\end{array}$ \\
\hline
\end{tabular}

${ }^{1}$ The response time given in the parentheses is the average response time of common contact managers that are built-in with mobile devices (as estimated for this scope). However, the success threshold for the accessible contact manager are higher, as may noticed, since the application is much more demanding graphically and it takes much more time to navigate. 
Table 1. (continued)

Accessibility - Text alternatives (WCAG 2.0 Guideline 1.1 [5]) Provide text alternatives for any non-text content so that it can be changed into other forms people need, such as large print, Braille, speech, symbols or simpler language

Accessibility - Time based Media (WCAG 2.0 Guideline 1.2). Provide alternatives for timebased media

Accessibility - Adaptable. WCAG 2.0 Guideline 1.3 - Create content that can be presented in different ways (for example simpler layout) without losing information or structure

Accessibility - Distinguishable. WCAG 2.0 Guideline 1.4 - Make it easier for users to see and hear content including separating foreground from background
Manual Evaluation

Manual Evaluation

Manual Evaluation

Manual evaluation for adequate sound level of voices and colour contrast analyser application to measure the minimum contrast
Every symbol presented to the user are provided is a text alternative

An alternative for time-based media (the audio voices of the contacts) is provided that presents equivalent information with other alternatives (textual - names of the contacts and/or graphical - pictures)

The application should be adaptable in at least two of the following: adapting layout, menus, font size, colour themes, language

- At least one of the colour themes should provide visual presentation of text and images (except images of contacts) of at least 4,5:1

- Colour is not used as the only visual means of conveying information

- Text can be resized without loss of content or functionality

- Sounds and voices should provide an adequate level of volume to be intelligible

\section{Results}

The following table shows the results of the technical validation according the Key indicators shown in Table 1. 
Table 2. Aggregated evalua tion results of the Accessible Contact Manager

\begin{tabular}{|c|c|c|c|c|}
\hline $\begin{array}{l}\text { Technical Key } \\
\text { Indicators }\end{array}$ & $\begin{array}{l}\text { Iterations } \\
\text { (number if } \\
\text { available) }\end{array}$ & $\begin{array}{l}\text { Mobile } \\
\text { Device }\end{array}$ & $\begin{array}{l}\text { Success } \\
\text { Threshold (for } \\
\text { each metric) }\end{array}$ & $\begin{array}{l}\text { Aggregated result } \\
\text { (per task scenario } \\
\text { if more than one) }\end{array}$ \\
\hline $\begin{array}{l}\text { Timeliness - Response } \\
\text { time in a navigation } \\
\text { movement using the } \\
\text { joystick }\end{array}$ & 5 & $\begin{array}{l}\text { Sony } \\
\text { Ericsson } \\
\text { Xperia } \\
\text { X2 }\end{array}$ & $\begin{array}{l}2 \text { seconds }(0,2 \\
\text { seconds })^{2}\end{array}$ & 1,620 seconds \\
\hline \multirow{2}{*}{$\begin{array}{l}\text { Timeliness - Response } \\
\text { time in a navigation } \\
\text { movement using } \\
\text { gestures with } \\
\text { touch-screen }\end{array}$} & 5 & $\begin{array}{l}\text { Sony } \\
\text { Ericsson } \\
\text { Xperia } \\
\text { X20 }\end{array}$ & $\begin{array}{l}2 \text { seconds }(0,2 \\
\text { seconds })\end{array}$ & 1,430 \\
\hline & 5 & $\begin{array}{l}\text { HTC HD } \\
2\end{array}$ & $\begin{array}{l}2 \text { seconds }(0,2 \\
\text { seconds })\end{array}$ & 1,123 \\
\hline \multirow{2}{*}{$\begin{array}{l}\text { Timeliness - Response } \\
\text { time in a modification } \\
\text { of the layout of the } \\
\text { application }\end{array}$} & 5 & $\begin{array}{l}\text { Sony } \\
\text { Ericsson } \\
\text { Xperia } \\
\text { X2 }\end{array}$ & $\begin{array}{l}15 \text { seconds } \\
\text { (feature not } \\
\text { available in } \\
\text { common } \\
\text { contact } \\
\text { managers) }\end{array}$ & 13,463 \\
\hline & 5 & $\begin{array}{l}\text { HTC HD } \\
2\end{array}$ & $\begin{array}{l}15 \text { seconds } \\
\text { (feature not } \\
\text { available in } \\
\text { common } \\
\text { contact } \\
\text { managers) }\end{array}$ & 4,644 \\
\hline \multirow{2}{*}{$\begin{array}{l}\text { Reliability - Number of } \\
\text { errors }\end{array}$} & 100 & $\begin{array}{l}\text { Sony } \\
\text { Ericsson } \\
\text { Xperia } \\
\text { X2 }\end{array}$ & $\begin{array}{l}\text { Less than one } \\
\text { error message } \\
\text { per } 50 \text { user } \\
\text { interactions } \\
\text { with the device }\end{array}$ & No error messages \\
\hline & 100 & $\begin{array}{l}\text { HTC HD } \\
2\end{array}$ & $\begin{array}{l}\text { Less than one } \\
\text { error message } \\
\text { per } 50 \text { user } \\
\text { interactions } \\
\text { with the device }\end{array}$ & No error messages \\
\hline
\end{tabular}

${ }^{2}$ The same as in footnote ${ }^{1}$ 
Table 2. (continued)

\begin{tabular}{|c|c|c|c|c|}
\hline $\begin{array}{l}\text { Accessibility - Text } \\
\text { alternatives (WCAG } 2.0 \\
\text { Guideline 1.1) - Provide } \\
\text { text alternatives for any } \\
\text { non-text content so that } \\
\text { it can be changed into } \\
\text { other forms people } \\
\text { need, such as large } \\
\text { print, braille, speech, } \\
\text { symbols or simpler } \\
\text { language }\end{array}$ & $\begin{array}{l}\text { All icons } \\
\text { were } \\
\text { reviewed }\end{array}$ & $\begin{array}{l}\text { This } \\
\text { metric } \\
\text { does not } \\
\text { depend } \\
\text { on a } \\
\text { particular } \\
\text { mobile } \\
\text { device }\end{array}$ & $\begin{array}{l}\text { Every symbol } \\
\text { presented to } \\
\text { the user are } \\
\text { provided is a } \\
\text { text alternative }\end{array}$ & $\begin{array}{l}\text { The success criteria } \\
\text { was met and all } \\
\text { symbols were } \\
\text { provided with text } \\
\text { alternatives }\end{array}$ \\
\hline $\begin{array}{l}\text { Accessibility - Time } \\
\text { based Media (WCAG } \\
\text { 2.0 Guideline 1.2). } \\
\text { Provide alternatives for } \\
\text { time-based media. }\end{array}$ & $\begin{array}{l}\text { All sounds } \\
\text { were } \\
\text { reviewed }\end{array}$ & $\begin{array}{l}\text { This } \\
\text { metric } \\
\text { does not } \\
\text { depend } \\
\text { on a } \\
\text { particular } \\
\text { mobile } \\
\text { device }\end{array}$ & $\begin{array}{l}\text { An alternative } \\
\text { for time-based } \\
\text { media (the } \\
\text { audio voices of } \\
\text { the contacts) is } \\
\text { provided that } \\
\text { presents } \\
\text { equivalent } \\
\text { information } \\
\text { with other } \\
\text { alternatives } \\
\text { (textual - } \\
\text { names of the } \\
\text { contacts and/or } \\
\text { graphical - } \\
\text { pictures) }\end{array}$ & $\begin{array}{l}\text { The success criteria } \\
\text { was met and all } \\
\text { audio sounds were } \\
\text { provided with text } \\
\text { alternatives }\end{array}$ \\
\hline $\begin{array}{l}\text { Accessibility - } \\
\text { Adaptable. WCAG } 2.0 \\
\text { Guideline } 1.3 \text { - Create } \\
\text { content that can be } \\
\text { presented in different } \\
\text { ways (for example } \\
\text { simpler layout) without } \\
\text { losing information or } \\
\text { structure }\end{array}$ & $\begin{array}{l}12 \\
\text { configurations } \\
\text { were tested }\end{array}$ & $\begin{array}{l}\text { This } \\
\text { metric } \\
\text { does not } \\
\text { depend } \\
\text { on a } \\
\text { particular } \\
\text { mobile } \\
\text { device }\end{array}$ & $\begin{array}{l}\text { The application } \\
\text { should be } \\
\text { adaptable in at } \\
\text { least two of the } \\
\text { following: } \\
\text { adapting } \\
\text { layout, menus, } \\
\text { font size, } \\
\text { colour themes, } \\
\text { language }\end{array}$ & $\begin{array}{l}\text { The success criteria } \\
\text { was met and the } \\
\text { application provided } \\
4 \text { methods that } \\
\text { allow users to adapt } \\
\text { the application to } \\
\text { their preferences: } \\
\text { layout, font size, } \\
\text { colour themes and } \\
\text { language }\end{array}$ \\
\hline $\begin{array}{l}\text { Accessibility - } \\
\text { Distinguishable. } \\
\text { WCAG } 2.0 \text { Guideline } \\
1.4 \text { - Make it easier for } \\
\text { users to see and hear } \\
\text { content including } \\
\text { separating foreground } \\
\text { from background }\end{array}$ & $\begin{array}{l}2 \text { colour } \\
\text { themes were } \\
\text { tested }\end{array}$ & $\begin{array}{l}\text { This } \\
\text { metric } \\
\text { was } \\
\text { tested } \\
\text { using the } \\
\text { mobile } \\
\text { emulator } \\
\text { running } \\
\text { on a } \\
\text { desktop } \\
\text { computer }\end{array}$ & $\begin{array}{l}\text { At least one of } \\
\text { the colour } \\
\text { themes should } \\
\text { provide visual } \\
\text { presentation of } \\
\text { text and } \\
\text { images (except } \\
\text { images of } \\
\text { contacts) of at } \\
\text { least } 4,5: 1 .\end{array}$ & $\begin{array}{l}\text { The success criteria } \\
\text { was met and the } \\
\text { minimum contrast } \\
\text { ratio was } 11,6 \text { for } \\
\text { the dark colour } \\
\text { theme. The other } \\
\text { colour theme has a } \\
\text { minimum contrast } \\
\text { ratio of } 4,6 \text { which is } \\
\text { also above the } \\
\text { threshold }\end{array}$ \\
\hline
\end{tabular}


Table 2. (continued)

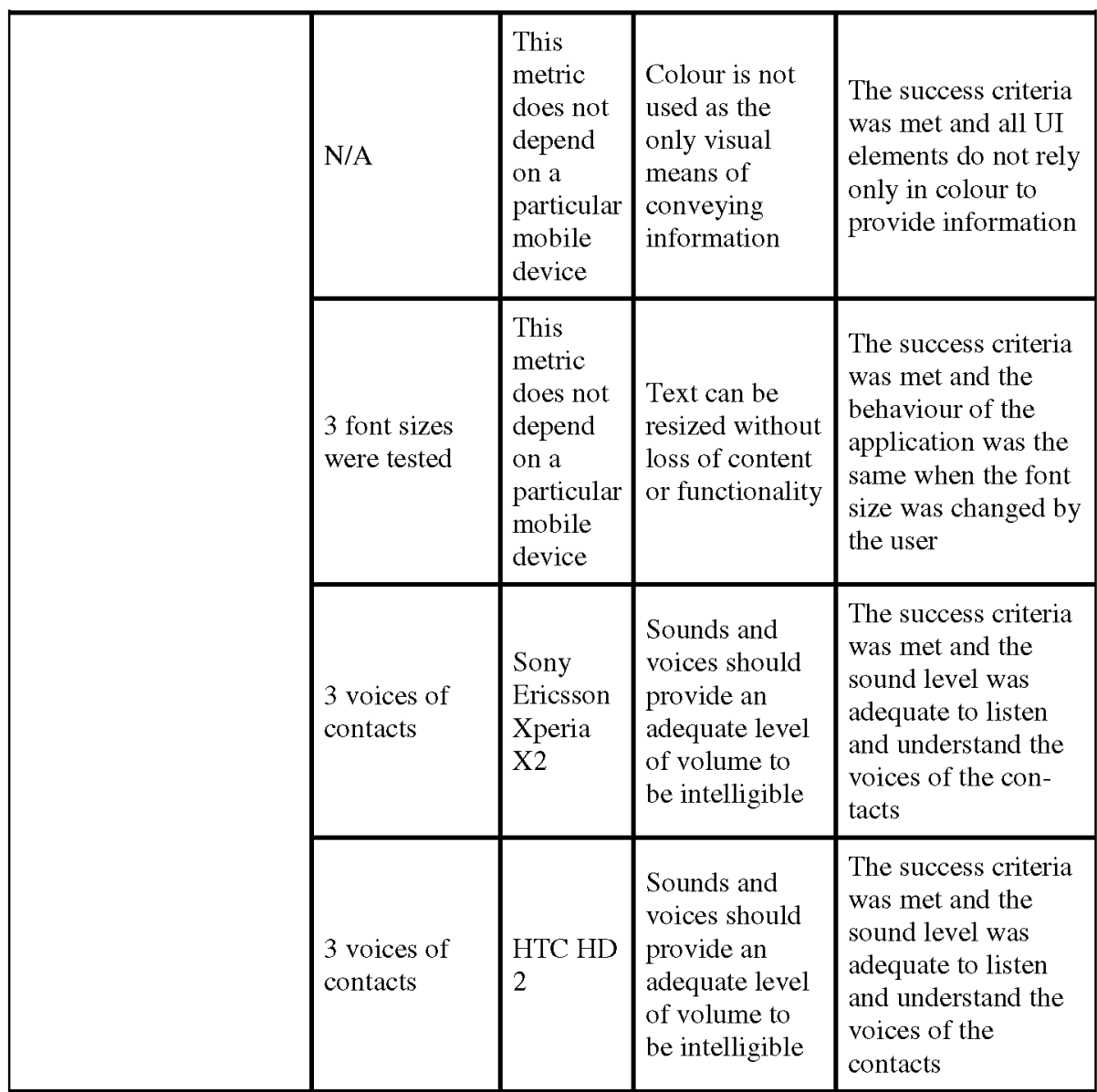

The accessible contact manager application has an important number of functionalities that are not included in conventional contact manager applications. Therefore, the response times have not been comparable to these built-in applications but have successfully improved the threshold values. It should be noticed the improvements of HTC HD2 in comparison with the Sony Ericsson X2, not only in response time but also in user navigation which is much more friendly as it uses a capacitive touch screen that does not require the use of a stylus.

The accessible contact manager has proven to be a very flexible and adaptable application for the users. The research hypothesis and the success criteria have been largely met. The prototype has worked without any error messages or further problems. In addition, the application has been able to adapt its layout and contents according to the user preferences taking into account the mobile device limitations. 


\section{Future Work}

The main problems that occurred during the technical validation were due to the use of the resistive touch-screen without using a stylus. The navigation was much better with the capacitive touch-screen of the HTC HD2 in comparison with the resistive touch-screen of the Sony Ericsson Xperia X2. This should be taken into account for future decisions on which devices are going to be used during the trials, because it affects the user experience and especially those who are motor impaired. In the near future the final application of the Accessible Contact Manager will be again evaluated taking into account the results of the human factors evaluation and the technical validation presented in this paper, checking if the improvements made into the applications will fulfil the technical recommendations and users needs.

Acknowledgment. This work has been carried out as part of the AEGIS (Open Accessibility Everywhere: Ground-work, Infrastructure, Standards) project co-funded by the European Commission under the Seventh Framework Programme funding for Research on e-Inclusion, grant agreement No. 224348.

\section{References}

1. AEGIS "Open Accessibility Everywhere: Groundwork, Infrastructure, Standards" project. IST-224348

2. Gemou, M., Bekiaris, E., Montalva, J., Cabrera, M.F., Colven, D., Rojo, I.C.: Novel framework and supporting material for the inclusive evaluation of ICT, AEGIS project, CN. 224348, 7th Framework Programme, ICT \& Ageing (May 2010)

3. King, T.W.: Assistive technology: essential human factors. Allyn and Bacon, Boston (1999)

4. Scholtz, J.: Usability Evaluation. National Institute of Standards and Technology (2004)

5. Caldwell, B., Cooper, M., Reid, L.G., Vanderheiden, G.: Web Content Accessibility Guidelines (WCAG) 2.0. W3C Recommendation, December 11 (2008) 